\title{
Mental Training Skills of Athletes According to Various Variables
}

\author{
Yasemin ARI' ${ }^{1}$ (D) , Kezban GÜLŞEN EŞKIL² (D), Remzi EŞKIL² (D) , \\ Ekrem Levent ILHAN ${ }^{3}$
}
1Tekirdağ Namık Kemal University School of Physical Education and Sports, TEKiRDAĞ
${ }^{2}$ Gazi University Institute of Educational Sciences, ANKARA
${ }^{3}$ Gazi University Faculty of Sports Sciences, ANKARA

Research Article

DOI:10.53434/gbesbd.951209

\begin{abstract}
This study was carried out based on the scanning model in order to examine the mental training skill profiles of athletes according to different variables. 417 athletes (Mean age $=20.62 \pm 1.97$ ) participated in the study voluntarily. Personal Information Form and Mental Training Inventory in Sports were applied to the participants. SPSS 25.00 package program was used for data analysis. Data were analyzed with descriptive statistics, T-test for Independent Groups and Pearson Product Moments Correlation. In the findings obtained, in terms of interpersonal skills, female athletes are ahead of male athletes and team athletes than individual athletes; in view of the basic mental skills sub-dimension, it was found that the average scores of individual athletes were higher than team athletes, and the mental visualization skills of national athletes were higher than non-national athletes $(p<0.05)$. A low level positive and significant relationship was found out between sports age and basic mental skill, mental performance skills and mental visualization skills ( $p<0.05)$. As a result, it was determined that the mental training skill profiles of the athletes participating in this study differed according to their gender, sports branch and nationality.
\end{abstract}

Keywords: Athlete, Mental training, Sport

Received/Geliş Tarihi: 11.06.2021 Accepted/Kabul Tarihi: 08.12.2021 Published/Yayın Tarihi: 27.01.2022 Ethics Committee Approval: This research was approved by the Scientific Research and Publication Ethics Committee of Tekirdağ Namık Kemal University with the number T2020-500 on 16.09.2020. 


\section{Farklı Değişkenlere Göre Sporcuların Zihinsel Antrenman Becerileri}

Öz

Bu araştırma, farklı değişkenlere göre sporcuların zihinsel antrenman beceri profillerinin incelenmesi amacıyla tarama modeline dayalı olarak yapıldı. Çalışmaya 417 sporcu (Yaş Ort.=20.62 \pm 1.97$)$ gönüllü olarak katıldl. Katılımcılara, Kişisel Bilgi Formu ve Sporda Zihinsel Antrenman Envanteri (SZAE) uygulandı. Verilerin analizi için SPSS 25.00 paket programı kullanıldı. Veriler, betimsel istatistikler, Bağımsız Gruplar için T-testi ve Pearson Momentler Çarpımı Korelasyon ile analiz edildi. Elde edilen bulgularda, kişiler arası becerilerde kadın sporcuların erkek sporculardan ve takım sporcuları bireysel sporculardan daha yüksek olduğu; zihinsel temel becerileri alt boyutunda ise bireysel sporcuların takım sporculardan ortalama puanlarının yüksek olduğu ve milli olan sporcuların zihinde canlandırma becerilerinin milli olmayan sporculardan daha yüksek olduğu bulundu $(p<0.05)$. Spor yașı ile zihinsel temel beceri, zihinsel performans becerileri ve zihinsel canlandırma becerileri arasında düşük düzeyde pozitif yönde anlamlı bir ilişki tespit edildi (p<0.05). Sonuç olarak, bu ç.alışmaya katılan sporcuların zihinsel antrenman beceri profillerinin cinsiyet, spor branșı ve milli olma durumlarına göre farklılaştığı belirlendi.

Anahtar sözcükler: Sporcu, Zihinsel antrenman, Spor

\section{Introduction}

Although a lot of trainers ground on solely physical training, researches show that the performance of athletes in the world is not only composed of conditional, technical and tactical elements, and the psychological aspect of training is complementary to other (conditional, tactical, technical) elements (Erdoğan, Zekioğlu \& Dorak, 2014). Bompa and Haff (2017) bases a good training program on these four main elements: psychological, conditional, tactical and technical.

Nowadays, with the understanding of the psychological factors in athlete performance, athletes take advantage of mental training as well as conditional training (Altıntaş \& Akalan, 2008). Hecker and Kaczor (1988) defined mental training as visualizing the movements or skills to be performed during competition or training without applying them (cited in Erdoğan \& Gülşen, 2020). On the other hand, Weinberg and Gould (2014) express mental training as performing psychological and mental practices in a consistent and systematic manner in order to increase performance, to get pleasure from physical activity and to provide satisfaction. In addition to these definitions, it is stated to be an important tool used to optimize these skills after basic movement skills are acquired (Cocks, Moulton, Luu \& Cil, 2014).

Athlete, in mental training, generally thinks about any skill and exercises the movement through observation and mental stimulation (Konter, 1999). Mental training not only helps to demonstrate the skill better, but also enables athletes to develop their intended task (Akandere, Aktaş \& Er, 2018). It also has a very suitable tool feature for correcting the technical errors experienced by the athlete (Bompa \& Haff, 2017). Scientific sources indicate that athletes who practice mental training show significantly higher 
performance than the ones who do not (Bompa \& Haff, 2017), and they have observed that they achieve better muscle control, ignore external effects and focus well at the end of the program (Tuna, 2018).

Çiftçi, Tolukan and Yılmaz (2021) stated that mental training techniques should be repeated many times as well as physical training for trainers and athletes. There are both experimental and descriptive studies about the importance of mental training and its effects on success in the relevant literature review. From this point of view, the aim of our study is to examine the mental training skill profiles of athletes based on the importance of their role in the training of athletes.

\section{Method}

\section{Model}

The research was designed in scanning model which is one of the quantitative research methods. The screening model is expressed as a study in which the ability, skills, opinions, interests or attitudes of the participants on a subject are measured and conducted on a larger number of participants (Büyüköztürk, Kılıç Çakmak, Akgün, Karadeniz \& Demirel, 2019).

\section{Participants}

The research group consists of 417 active athletes between the ages of 18-25 (Mean= 20.62; sd=1.975) engaged in individual and team sports. The sports year of the participants varies between 1-19 (Mean= 8.21; $\mathrm{sd}=3.974)$ years.

Table 1. Demographic information of the participants

\begin{tabular}{llll}
\hline Departments & Groups & Frequency & Percent \\
\hline \multirow{2}{*}{ Gender } & Male & 219 & 52.5 \\
& Female & 198 & 47.5 \\
\hline \multirow{2}{*}{ Sport } & Individual & 203 & 48.7 \\
& Team & 214 & 51.3 \\
\hline \multirow{2}{*}{ National Athlete } & Yes & 82 & 19.7 \\
\hline \multirow{2}{*}{ Total } & No & 335 & 80.3 \\
\hline
\end{tabular}

\section{Data Collection}

The form was sent to the athletes via e-questionnaire and e-mail because of the fact that the group to participate in the research was in different places due to the COVID-19 pandemic and it was convenient to reach them in this way. A total of 417 athletes, 197 of whom were female and 219 male, completed the scale form completely by e-mail and voluntarily participated in the study. 
Research Ethics: This study was conducted on the basis of the permission obtained by Tekirdağ Namık Kemal University Scientific Research and Publication Ethics Committee with the decision number T2020-500 dated 16.09.2020.

\section{Data Collection Tool}

The scale used in the study consists of 2 parts. One of these is the personal information form and it provides information about the participants' gender, national athletic status, sports (individual or team sports), age and sports age.

The Mental Training Inventory in Sports (SZAE), developed by Behnke, Tomczak, Kaczmarek, Komar and Gracz (2017) and adapted into Turkish by Yarayan and İlhan (2018), was usedin order to measure the mental training levels of the participants.

Mental Training Inventory in Sports (SZAE): This scale, developed to measure mental techniques and skills in sports environment, is a 5-point Likert-type scale consisting of 5 sub-dimensions and 20 items. The evaluation of the answers given to the questions is "I strongly agree 5, I absolutely disagree" 1 . The Kaiser-Meyer-Olkin" (KMO) value is 0.899 (x2 3247.940; sd 190; p .000.). In their study, Yarayan and İlhan (2018) stated that the variance of the 5 factor structure was $69.219 \%$. The factor loads of the "Basic Skills" subdimension were 0.54-0.78, the factor loads of the "Mental Performance Skills" subdimension 0.62-0.78, the factor loads of the "Interpersonal Skills" sub-dimension 0.79-0.86, the factor loadings of the "Speaking to Yourself" sub-dimension 0.87-0.95 and "The factor loads of the "Mental Enhancing" sub-dimension ranged between 0.75-0.87. Internal Consistency Coefficients for the sub-dimensions of Mental Training Inventory in Sport (Cronbach Alpha), Mental Basic Skills .82, Mental Performance Skills .85, Interpersonal Skills .85, Talking to Oneself .91, Mental Revitalization .82 and General Internal Consistency Coefficient of Inventory. 91 were found.

Percentage and frequency distributions were examined in order to observe the individual variables of the athletes in the analysis of the data obtained. National athletic status, age, sports age, sports (individual or team) and gender variables were used in order to examine the mental training skill profiles of the participants. First of all, whether the research group has a normal distribution was examined by using the skewness and kurtosis values. Independent Samples T-test was used in paired comparisons since normal distribution was obtained. "Pearson Moments Multiplication Analysis" was used to determine the relationship between sports age and mental training sub-dimensions.

All this analysis process was carried out with the SPSS (Statistical Package for the Social Sciences) for Windows 25 package software. Effect dimensions (Cohen's d) were calculated for the significance of the comparisons. Thresholds for effect size statistics are as follows: $<0.20=$ not important, 0.20-0.59 small, 0.6-1.19= medium, 1.2-1.99 = large, $\geq$ 2.0 very large (Hopkins, Marshall, Batterham \& Hanin, 2009). The significance level was taken as 0.05 . 
Table 2. Internal consistency coefficient of mental training inventory in sports $(\alpha)$

\begin{tabular}{lcc}
\hline Scales and Sub-Dimensions & Item Number & Cronbach Alpha $(\boldsymbol{\alpha})$ \\
\hline Mental training inventory in sports & 20 & .852 \\
Mental basic skills & 4 & .619 \\
Mental performance skills & 6 & .685 \\
Interpersonal skills & 4 & .760 \\
Intrapersonal & 3 & .804 \\
Mental visualization & 3 & .695 \\
\hline
\end{tabular}

In Table 2, it is considered sufficient for the reliability of the test scores that the Cronbach $\alpha$ coefficients of the attitude scale and sub-dimensions of the mental training inventory in sports are .60 and higher. In line with these findings, it has been concluded that the data obtained from the Mental Training Inventory in Sportsare reliable (Kalaycl, 2010).

\section{Results}

In this section, the sub-dimension scores obtained from the scales, the comparison of the mental training inventory in sports in terms of various variables, and the analyzes regarding the correlation between them have been presented.

Table 3. T-test analysis results showing sub-dimensions of mental training inventory in sports in terms of gender variable

\begin{tabular}{|c|c|c|c|c|c|c|c|c|c|}
\hline $\begin{array}{l}\text { Sub } \\
\text { dimension }\end{array}$ & Variable & $\mathbf{N}$ & Mean & Ss & f & $\mathbf{t}$ & df & $\mathbf{p}$ & $\eta^{2}$ \\
\hline \multirow{2}{*}{$\begin{array}{l}\text { Mental basic } \\
\text { skills }\end{array}$} & Male & 219 & 4.0845 & .51385 & \multirow{2}{*}{3.012} & \multirow{2}{*}{-.884} & \multirow[b]{2}{*}{415} & \multirow[b]{2}{*}{.377} & \\
\hline & Female & 198 & 4.1313 & .56813 & & & & & \\
\hline \multirow{2}{*}{$\begin{array}{l}\text { Mental } \\
\text { performance } \\
\text { skills }\end{array}$} & Male & 219 & 3.8006 & .52030 & \multirow[b]{2}{*}{1.022} & \multirow[b]{2}{*}{1.712} & \multirow[b]{2}{*}{415} & \multirow[b]{2}{*}{.088} & \\
\hline & Female & 198 & 3.7096 & .56499 & & & & & \\
\hline \multirow{2}{*}{$\begin{array}{l}\text { Interpersonal } \\
\text { skills }\end{array}$} & Male & 219 & 4.2397 & .51487 & \multirow{2}{*}{.194} & \multirow{2}{*}{-3.876} & \multirow{2}{*}{415} & \multirow{2}{*}{.000} & \multirow{2}{*}{.381} \\
\hline & Female & 198 & 4.4268 & .46550 & & & & & \\
\hline \multirow{2}{*}{$\begin{array}{l}\text { Intrapersonal } \\
\text { skills }\end{array}$} & Male & 219 & 3.8524 & .72737 & \multirow{2}{*}{2.517} & \multirow{2}{*}{-2.392} & \multirow{2}{*}{415} & \multirow{2}{*}{.017} & \multirow{2}{*}{.234} \\
\hline & Female & 198 & 4.0185 & .68683 & & & & & \\
\hline \multirow{2}{*}{$\begin{array}{l}\text { Mental } \\
\text { Visualization } \\
\text { Skills } \\
\end{array}$} & Male & 219 & 4.0776 & .62611 & \multirow{2}{*}{3.438} & \multirow{2}{*}{-1.376} & \multirow{2}{*}{415} & \multirow{2}{*}{.170} & \\
\hline & Female & 198 & 4.1566 & .53597 & & & & & \\
\hline
\end{tabular}

According to the Table 3, a significant difference has been found in the subdimensions of interpersonal skills and internal speaking skills of male and female athletes $(\mathrm{p}<0.05)$. Considering the effect size value, it has been determined that the female and male athletes' variable had a small effect on interpersonal skills $\left(\eta^{2}=.381\right)$ and intrapersonal skills $\left(\eta^{2}=.234\right)$ sub-dimensions. 
Table 4. T-test analysis results showing sub-dimensions of mental training inventory in sports in terms of sport branch

\begin{tabular}{|c|c|c|c|c|c|c|c|c|c|}
\hline $\begin{array}{l}\text { Sub } \\
\text { dimension }\end{array}$ & Variable & $\mathbf{N}$ & Mean & Ss & $\mathbf{f}$ & $\mathbf{t}$ & df & $\mathbf{p}$ & $\eta^{2}$ \\
\hline \multirow{2}{*}{$\begin{array}{l}\text { Mental basic } \\
\text { skills }\end{array}$} & $\begin{array}{l}\text { Individual } \\
\text { sports }\end{array}$ & 203 & 4.1613 & & \multirow[t]{2}{*}{1.812} & \multirow[t]{2}{*}{2.018} & \multirow[t]{2}{*}{415} & \multirow{2}{*}{$\begin{array}{c}.04 \\
4\end{array}$} & \multirow[t]{2}{*}{.198} \\
\hline & Team sports & 214 & 4.0549 & .57088 & & & & & \\
\hline \multirow{2}{*}{$\begin{array}{l}\text { Mental } \\
\text { performance } \\
\text { skills }\end{array}$} & $\begin{array}{l}\text { Individual } \\
\text { sports }\end{array}$ & 203 & & & \multirow[t]{2}{*}{.961} & \multirow{2}{*}{$\begin{array}{c}- \\
1.642\end{array}$} & \multirow[t]{2}{*}{415} & \multirow[t]{2}{*}{.101} & \\
\hline & Team sports & 214 & 3.7998 & .55996 & & & & & \\
\hline \multirow{2}{*}{$\begin{array}{l}\text { Interpersonal } \\
\text { skills }\end{array}$} & $\begin{array}{l}\text { Individual } \\
\text { sports }\end{array}$ & 203 & 4.2759 & .47487 & \multirow[t]{2}{*}{3.054} & \multirow{2}{*}{2.103} & \multirow[t]{2}{*}{415} & \multirow{2}{*}{$\begin{array}{c}.03 \\
6\end{array}$} & \multirow[t]{2}{*}{.206} \\
\hline & Team sports & 214 & 4.3785 & .51942 & & & & & \\
\hline \multirow{2}{*}{$\begin{array}{l}\text { Intrapersonal } \\
\text { skills }\end{array}$} & $\begin{array}{l}\text { Individual } \\
\text { sports }\end{array}$ & 203 & 3.9392 & .66512 & \multirow[t]{2}{*}{5.018} & \multirow[t]{2}{*}{.223} & \multirow[t]{2}{*}{415} & \multirow[t]{2}{*}{.824} & \\
\hline & Team sports & 214 & 3.9237 & .75605 & & & & & \\
\hline \multirow{2}{*}{$\begin{array}{l}\text { Mental } \\
\text { visualization } \\
\text { skills }\end{array}$} & $\begin{array}{l}\text { Individual } \\
\text { sports }\end{array}$ & 203 & 4.1215 & .59287 & \multirow[t]{2}{*}{.033} & \multirow[t]{2}{*}{.217} & \multirow[t]{2}{*}{415} & \multirow[t]{2}{*}{.828} & \\
\hline & Team sports & 214 & 4.1090 & .58010 & & & & & \\
\hline
\end{tabular}

According to the Table 4, a significant difference has been found between individual and team athletes in terms of mental basic skills and interpersonal skills sub-dimensions $(p<0.05)$. Considering the effect size value, it has been determined that it has an insignificant effect on the mental basic skills dimension $\left(\eta^{2}=.198\right)$ in terms of the individual and team sports variable $\left(\eta^{2}=.198\right)$, while it has a small effect on the interpersonal skills dimension $\left(\eta^{2}=.206\right)$.

Table 5. T-test analysis results showing sub-dimensions of mental training inventory in sports in terms of being national athlete

\begin{tabular}{|c|c|c|c|c|c|c|c|c|c|}
\hline Sub dimension & Vari. & $\mathbf{N}$ & Mean & Ss & f & $\mathbf{t}$ & df & $\mathbf{p}$ & $\eta^{2}$ \\
\hline \multirow{2}{*}{$\begin{array}{l}\text { Mental basic } \\
\text { skills }\end{array}$} & Yes & 82 & 4.1738 & .47579 & \multirow{2}{*}{2.253} & \multirow{2}{*}{1.255} & \multirow{2}{*}{415} & \multirow{2}{*}{.210} & \\
\hline & No & 335 & 4.0903 & .55419 & & & & & \\
\hline \multirow{2}{*}{$\begin{array}{l}\text { Mental } \\
\text { performance } \\
\text { skills }\end{array}$} & Yes & 82 & 3.7114 & .59608 & \multirow[b]{2}{*}{.616} & \multirow[b]{2}{*}{-.855} & \multirow[b]{2}{*}{415} & \multirow[b]{2}{*}{.393} & \\
\hline & No & 335 & 3.7687 & .52984 & & & & & \\
\hline \multirow{2}{*}{$\begin{array}{l}\text { Interpersonal } \\
\text { skills }\end{array}$} & Yes & 82 & 4.3110 & .52199 & \multirow{2}{*}{.014} & \multirow{2}{*}{-.354} & \multirow{2}{*}{415} & \multirow{2}{*}{.723} & \\
\hline & No & 335 & 4.3328 & .49553 & & & & & \\
\hline \multirow{2}{*}{$\begin{array}{l}\text { Intrapersonal } \\
\text { skills }\end{array}$} & Yes & 82 & 3.9431 & .65380 & \multirow{2}{*}{.697} & \multirow{2}{*}{.168} & \multirow{2}{*}{415} & \multirow[b]{2}{*}{.867} & \\
\hline & No & 335 & 3.9284 & .72695 & & & & & \\
\hline \multirow{2}{*}{$\begin{array}{l}\text { Mental } \\
\text { visualization } \\
\text { skills } \\
\end{array}$} & Yes & 82 & 4.2520 & .55817 & \multirow[b]{2}{*}{.054} & \multirow[b]{2}{*}{2.375} & \multirow[b]{2}{*}{415} & \multirow[b]{2}{*}{.018} & \multirow[b]{2}{*}{.297} \\
\hline & No & 335 & 4.0816 & .58818 & & & & & \\
\hline
\end{tabular}

According to the Table 5, a significant difference has been found between national and non-national athletes in the sub-dimension of mental visualization skills $(\mathrm{p}<0.05)$. Considering the effect size value, it has been determined that it has a small effect on the mental stimulation skills sub-dimension in terms of being a national athlete variable $\left(\eta^{2}=\right.$ .297). 
Table 6. Correlation table of sports age variable and mental training sub-dimensions

\begin{tabular}{|c|c|c|c|c|c|c|c|}
\hline & & $\begin{array}{l}\text { Sport } \\
\text { age }\end{array}$ & $\begin{array}{c}\text { Mental } \\
\text { basic skill }\end{array}$ & $\begin{array}{c}\text { Mental } \\
\text { performance } \\
\text { skills }\end{array}$ & $\begin{array}{l}\text { Interpersonal } \\
\text { skills }\end{array}$ & $\begin{array}{l}\text { Intrapersonal } \\
\text { skills }\end{array}$ & $\begin{array}{c}\text { Mental } \\
\text { visualization } \\
\text { skills }\end{array}$ \\
\hline Sport age & $\mathrm{r}$ & 1 & & & & & \\
\hline $\begin{array}{l}\text { Mental basic } \\
\text { skill }\end{array}$ & $\mathrm{r}$ & $.135^{* *}$ & 1 & & & & \\
\hline $\begin{array}{l}\text { Mental } \\
\text { performance } \\
\text { skills }\end{array}$ & $r$ & $.181^{* *}$ & $.492^{* *}$ & 1 & & & \\
\hline $\begin{array}{l}\text { Interpersonal } \\
\text { skills }\end{array}$ & $\mathrm{r}$ & .073 & $.532^{* *}$ & $.474^{* *}$ & 1 & & \\
\hline $\begin{array}{l}\text { Intrapersonal } \\
\text { skills }\end{array}$ & $\mathrm{r}$ & .087 & $.330^{* *}$ & $.197^{* *}$ & $.344^{* *}$ & 1 & \\
\hline $\begin{array}{l}\text { Mental } \\
\text { visualization } \\
\text { skills }\end{array}$ & $\mathrm{r}$ & $.128^{* *}$ & $.407^{* *}$ & $.274^{* *}$ & $.539^{* *}$ & $.314^{* *}$ & 1 \\
\hline
\end{tabular}

As it is seen in Table 6, a low level positive and significant relationship has been found between the sports age of the participants and mental basic skills, mental performance skills and mental visualization skills $(\mathrm{p}<0.05)$.

\section{Discussion}

In the study, mental training skill levels of the athletes were examined according to different variables. According to the findings of this research, it was found that the average scores of the participants from the mental training inventory in sports were high. As a result of the analyzes made on the research group included in the study, a significant difference was found in the mental training levels of the athletes in terms of gender variable in the sub-dimensions of interpersonal skills and internal speaking skills; in basic mental skills and interpersonal skills sub-dimensions in terms of individual and team sports variables; in the visualization skills sub-dimension in terms of being a national athlete variable. While there was no significant difference in gender variable in mental basic skills, mental performance skills and mental stimulation skills sub-dimensions, a statistically significant difference was found in favor of female athletes in interpersonal skills and intrapersonal skills sub-dimensions. In this direction, it can be said that female athletes have higher ability to work with others and higher self-awareness levels than male athletes. Kara and Hoşver (2019) stated that female volleyball players' mental training levels in sports are above their average scores. When the literature is reviewed, there are also studies reporting that male athletes have higher mental skills than female athletes, unlike the findings of this study (Behnke et al., 2017; Çelik \& Güngör, 2020; Nicholls, Polman, Levy \& Backhouse, 2009; Öner \& Cankurtaran, 2020; Turgut \& Yasar, 2019; Zengin \& Kırkbir, 2020). However, Habacha, Molinaro and Dosseville (2014) stated in their study that gender is a parameter that should be taken into consideration. 
In this study, important differences were found between athletes who do different sports branches. The mean scores of the sub-dimension of the mental basic skills were found to be higher in the participants who do individual sports while the scores of the interpersonal skills sub-dimension were higher in the athletes engaged in team sports. Unlike these findings, it was observed that there was no statistically significant difference in the comparison of the sub-dimensions of mental performance skills, intrapersonal skills and mental visualization skills of athletes. Zengin and Kırkbir (2020) have established higher average scores of athletes interested in team sports in sub-dimensions of basic mental skills, mental performance skills, interpersonal skills and mental visualization skills. Additionally, Çelik and Güngör (2020) have stated that mental performance skills differ statistically according to the sports branch. They have pointed out that the level of using mental performance skills of athletes who are interested in individual sports is higher than those who practice any team sport. It is also seen that there are studies with different findings when the current literature is examined. Erdoğan and Gülșen (2020) determined that there was no significant difference between the mental training sub-dimensions according to the branch variable of the athletes studying at the faculty of sports sciences. Turgut and Yaşar (2020) have stated that there is no statistically significant difference in mental training levels between players interested in different team sports. In accordance with the researches, it can be said that there are different findings in terms of the sports branches variable.

A significant difference has been found in the mean scores of the visualization subdimension in the variable of being a national athlete which is another finding of the study. Erdoğan and Gülşen (2020) have stated that there is a significant difference in the visualization sub-dimension in terms of the nationality variable of athletes and that the average of national athletes is higher than non-national athletes. Findings obtained in the light of these results are parallel. In another similar study, they reported that there was a significant difference in the mental training levels of amateur and professional athletes and that the average scores of mental training were higher in favor of professional athletes (Zengin \& Kırkbir, 2020). Turgut and Yaşar (2019) have found that professional athletes' level of using their mental training skills is above average. In line with these results, it is thought that factors such as the number of national and professional athletes participating in national and international competitions, training frequency and competition experience may be effective on the mental training levels of the athletes.

In addition, a significant relationship was found between the sports age of the participants and the sub-dimensions of mental basic skills, mental performance skills, and mental visualization skills. In accordance with these findings, it can be said that as athletes' competition experiences and years of doing sports increase, their mental training skills will increase. Çelik and Güngör (2020) have reported that there is a positive and significant relationship between sports age and mental basic skills, mental performance skills, interpersonal skills and mental training total scores in sports. Nevertheless, there are studies conducted on the correlation of sports age and mental training within the scope of 
the current literature (Cankurtaran, 2020; Erdoğan \& Gülșen, 2020; Kara \& Hoşver, 2019; Öner \& Cankurtaran, 2020; Turgut \& Yasar, 2019).

Before the final conclusions were drawn, the analysis of the athletes participating in this study for a certain age group and the evaluation of the mental training skills of the athletes with only a scale was determined as a limitation of the study considering the universe of the athletes. However, the importance of this research is thought to contribute positively to the performance development of athletes by increasing their mental training skill levels.

\section{Conclusion}

As a result, the mental training skills of the athletes in sports and gender, sports branch, status of being a national athlete and sports age variables were examined. It was determined that the average scores of mental training skills in sports of the participants in this study group were high. As a result of the statistical data obtained, it was found that female athletes had higher mental training skills in sports than male athletes. In addition, istatistical difference has been determined in the sub-dimensions of basic mental skills and interpersonal skills of athletes who are interested in individual and team sports; in the mental visualization skills in the sub-dimension in the comparison of national athletes and non-national athletes. In line with these results, it is thought that mental training skills are the factor that affecting the physical and physiological performance of the athletes. For this reason, it is recommended to apply studies on the use of mental training skills of athletes along with experimental studies in future studies.

\section{Conflict of Interest}

There is no conflict of interest between the authors regarding the publication of this article.

\section{Author Contributions}

Research Idea: ELİ, KGE; Research Design: KGE, YA, RE; Analysis of Data: YA, RE; Writing: RE, KGE, YA; Critical Review: ELI

Yazışma Adresi (CorrespondingAddress):

Arș. Gör. Dr. Yasemin ARI

Tekirdağ Namık Kemal University, School of Physical Education and Sports, TEKIRDAĞ

ORCID: https://orcid.org/0000-0002-1241-1347

E-posta:yaseminari88@gmail.com 


\section{References}

1. Akandere, M., Aktaş, S., \& Er, Y. (2018). Zihinsel Antrenman ve Spor [Mental Training and Sports]. Ankara: Türkiye Barolar Birliği.

2. Altıntaş, A., \& Akalan, C. (2008). Zihinsel antrenman ve yüksek performans [Mental training and high performance]. Spormetre Beden Eğitimi ve Spor Bilimleri Dergisi, 6(1), 3943.

3. Behnke, M., Tomczak, M., Kaczmarek, L. D., Komar, M., \& Gracz, J. (2017). The sport mental training questionnaire: Development and validation. Current Psychology, 38(2), 504516.

4. Bompa, T., \& Haff, G. (2017). Dönemleme: Antrenman Kuramı ve Yöntemi [Periodization: Training Theory and Method]. Ankara: Spor.

5. Büyüköztürk, Ş., Kılıç Çakmak, E., Akgün, Ö., Karadeniz, Ş., \& Demirel, F. (2019). Eğitimde Bilimsel Araștırma Yöntemleri [Scientific Research Methods in Education]. Ankara: Pegem Yayıncllık.

6. Cankurtaran, Z. (2020). Okçuların rekabet ortamında kullandıkları zihinsel antrenman becerilerinin sıralama atış skorlarına etkisi [The effect of the mental training skills used by the archers in the competition environment on the ranking shot scores]. Uluslararası Güncel Eğitim Araştırmaları Dergisi, 6(1), 13-29.

7. Cocks, M., Moulton, C. A., Luu, S., \& Cil, T. (2014). What surgeons can learn from athletes: Mental practice in sports and surgery. Journal of Surgical Education, 71(2), 262-269.

8. Çelik, O. B., \& Güngör, N. B. (2020). The effects of the mental training skills on the prediction of the sports sciences faculty students' anxiety levels. International Journal of Eurasian Education and Culture, 9(9), 888-929.

9. Çiftçi, M. C., Tolukan, E., \& Yılmaz, B. (2021). Sporcuların zihinsel antrenman becerileri ile sürekli sportif öz güven düzeyleri arasındaki ilişki [The interaction between mental skills training and trait sports confidence level of athletes]. Gazi Beden Eğitimi ve Spor Bilimleri Dergisi, 26(1), 151-162.

10. Erdoğan, B. S., \& Gülşen, D. B. A. (2020). Spor bilimleri fakültesinde öğrenim gören sporcuların zihinsel antrenman düzeylerinin belirlenmesi [Determination of mental training levels of athletes studying in the faculty of sport sciences]. Akdeniz Spor Bilimleri Dergisi, 3(1), 219-228.

11. Erdoğan, N., Zekioğlu A., \& Dorak, F. (2014). Hentbol antrenörlerine göre, sporcuların performansını psikolojik yönden etkileyen faktörler nelerdir? Nitel çalışma [According to handball coaches, what are the psychological factors that affect the performance of athletes? A qualitative study]. International Journal of Sport Culture and Science, 2(Special Issue 1), 194-207.

12. Habacha, H., Molinaro, C., \& Dosseville, F. (2014). Effects of gender, imagery ability, and sports practice on the performance of a mental rotation task. The American Journal of Psychology, 127(3), 313-323.

13. Hopkins, W. G., Marshall, S. W., Batterham, A. M., \& Hanin, J. (2009). Progressive statistics for studies in sports medicine and exercise science. Medicine \& Science in Sports \& Exercise, 41(1), 3.

14. Kalaycı, Ş. (2010). SPSS Uygulamalı Çok Değişkenli İstatistik Teknikleri [SPSS Applied Multivariate Statistics Techniques]. Ankara: Asil Yayınları. 
15. Kara, Ö., \& Hoşver, P. U. (2019). Play-Off müsabakalarında yer alan kadın voleybolcuların zihinsel antrenman düzeylerinin çeşitli değişkenler açısından incelenmesi [Investigation of the mental training level of women volleyball player who take place in play-off competition in terms of some variables]. International Sport Science Student Studies, 1(1), 35-42.

16. Konter, E. (1999). Uygulamalı Spor Psikolojisinde Zihinsel Antrenman [Mental Training in Applied Sports Psychology]. Ankara: Nobel Yayınları.

17. Nicholls, A. R., Polman, R. C., Levy, A. R., \& Backhouse, S. H. (2009). Mental toughness in sport: Achievement level, gender, age, experience, and sport type differences. Personality and Individual Differences, 47(1), 73-75.

18. Öner, Ç., \& Cankurtaran, Z. (2020). Elit okçuların zihinsel beceri ve tekniklerinin atış performanslarını belirleyici rolü [The determinative role of the mental skills and techniques of elite archers in their shooting performance]. Uluslararası Egzersiz Psikolojisi Dergisi, 2(1), $1-9$.

19. Tuna, N. (2018). Biyolojik geri bildirimle zihinsel antrenman programinın sporcuların performansina etkisi (Yüksek lisans tezi). [The effect of mental training program with biological feedback on the performance of athletes]. Hacettepe Üniversitesi Sağllk Bilimleri Enstitüsü, Ankara.

20. Turgut, M., \& Yasar, O. M. (2020). Mental training of college student elite athletes. Journal of Education and Learning, 9(1), 51-59.

21. Weinberg, R. S., \& Gould, D. (2014). Foundations of sport and exercise psychology. Champaign: Human Kinetics.

22. Yarayan, Y. E., \& İlhan, E. L. (2018). Sporda zihinsel antrenman envanteri'nin (SZAE) uyarlama çalışması [The sport mental training questionnaire (SMTQ) adaptation study]. Gazi Beden Eğitimi ve Spor Bilimleri Dergisi, 23(4), 205-218.

23. Zengin, S., \& Kirkbir, F. (2020). Investigation of mental training in sports branches. International Journal of Applied Exercise Physiology, 9(10), 65-72. 